\title{
Public Health concern for a Nipah Virus disease
}

\author{
Surana Ajaykumar Rikhabchand, Manoj Ramesh Kumbhare, Apurva Uttamrao Abhale, \\ Ankita Ankush Bhoir, Shivam Puranmalgi Agrawal
}

S.M.B.T. College of Pharmacy, Dhamangaon, Tal-Igatpuri, Dist-Nashik, M.S., India-422403.

\begin{abstract}
Nipah virus $(\mathrm{NiV})$ is a pathogenic paramyxovirus that has been responsible for sporadic outbreaks of respiratory and encephalitic disease in tropical countries. Elevated case mortality rate has also been connected with recent outbreaks in India (Kerala), Malaysia and Bangladesh. The virus generally infects animals like pigs and bats, but they do not show any symptoms of $\mathrm{NiV}$. The mortality rate in NiV infected humans is more as compared to other mammals. The patient usually shows no symptoms to headache fever, cough, dyspnea, confusion and more consequences lead to a coma. Although there are no drugs or vaccines available against this severe disease, precaution and awareness reduce the risk of $\mathrm{NiV}$-infection. This review will be helpful to save the life of people and decrease death by NiV-infection outbreak.
\end{abstract}

Keywords: Diagnosis; Henipavirus; Nipah virus; Prevention and treatment.

\section{Etiology}

\section{Introduction}

Newly occurring viral diseases have a huge effect on community health in recent years. During past decades, many new viral outbreaks have been documented in the various parts of the Globe [1]. These outbreaks were owing to known viral agents like Crimean Congo haemorrhagic fever, Ebola virus disease as well as Nipah, Lassa fever, Marburg, Middle East respiratory syndrome, coronavirus diseases, Rift Valley fever and severe acute respiratory syndrome [2]. WHO has designated Zika, thrombocytopaenia syndrome and chikungunya as 'serious' diseases. These viral diseases are responsible for extensive mortality, morbidity and great economic loss throughout the world[3]. Yet older viruses like influenza are able to reemerge and cause current threats of the epidemic and pandemic [4]. These viruses infecting humans via direct contact or through infected animals. $\mathrm{NiV}$ infection is a recently occurring zoonosis that causes severe disease in mammals. Fruit bats of the genus Pteropus (Family Pteropodidae ) are the main host for NiV [5]. In 1998 Kampong Sungai Nipah (Malaysia) the first case of $\mathrm{NiV}$ was identified in pigs as intermediate hosts [6]. According to WHO research and development blueprint, $\mathrm{NiV}$ infection has high priority disease until no medication or vaccines is available for this lethal illness [7]. Supportive care is the preliminary treatment of NiV. Although $\mathrm{NiV}$ reported only a few epidemics the causalities were very high among the humans and animals. Almost $70-100 \%$ infected people die due to $\mathrm{NiV}$ epidemics as this is very serious public health concern [8]. This review will be useful to create awareness of $\mathrm{NiV}$ infection and save lives of human beings.

eISSN: 2523-6709

pISSN: 2523-6695

DOI: $10.31878 /$ ijcrpp.2019.34.3
Nipah virus from the genus Henipavirus (Paramyxoviridae). Nipah virus name came from the Malaysian village infection where the first case was reported. Bats do not show symptoms but only carriers of $\mathrm{NiV}$ and infected bats shed virus through their excretions and secretions products like excreta, urine semen and saliva [9]. Through coughing $\mathrm{NiV}$ is widely spread amongst pigs. Direct contact from infected pigs, bats and humans transmit $\mathrm{NiV}$ infection to human beings. In India and Bangladesh this serious infection transmitted directly from humans to humans through contact with infected humans and caused outbreaks [10]. In 2001, 75\% hospital employees and visitors in Siliguri in India, transmission of $\mathrm{NiV}$ from hospitalized patients were reported. In Bangladesh, Around $50 \%$ of cases from 2001 to 2008 were amongst caretakers of the $\mathrm{NiV}$ infected patients [10]. In 2001, an outbreak in Meherpur in Bangladesh found that persons who stayed with infected patients or cared for them were more possible to become infected with $\mathrm{NiV}$ [11].

\section{Structure of Nipah Virus}

Hendra virus and Cedar virus have a close resemblance to the newly formed genus Henipavirus i.e. Nipah virus. The diameter of Henipavirus family is 40 to $600 \mathrm{~nm}$ [12]. Negative sense single-stranded RNA and a linear ribonucleoprotein (RNP) comprises of the core of a virion. The three important proteins included in RNP. Nucleocapsid proteins are highly bound to the various nucleotides of the RNA strand (Figure 1) [13]. For formation of capsid structure, the Nucelocapsid proteins are the principal protein available. Phosphoproteins and polymerase proteins are also bound to the RNA and RNA polymerase in transcribing RNA to mRNA to antigenomic RNA. The virion is covered by a traditional lipid bilayer and also spiked with fusion and receptorbinding glycoproteins [14]. The release of the contents of the virion produces fusion proteins. The fusion proteins are responsible for fusing the viral membrane to the host membrane triggering.

Correspondence: Surana Ajaykumar Rikhabchand, S.M.B.T. College of Pharmacy, Dhamangaon, Tal-Igatpuri, Dist-Nashik, M.S., India-422403. E-Mail: ajaysurana01@rediffmail.com 


\section{Clinical Spectrum and laboratory diagnosis}

\section{Clinical Signs:}

Although some Nipah virus infections can be asymptomatic or mild, most recognized clinical cases have been characterized by respiratory disease and/or acute neurological signs. The initial symptoms are flulike, with fever, headache, sore throat and myalgia [16]. Nausea, vomiting and a nonproductive cough may also be seen. This prodromal syndrome may be followed by encephalitis, with symptoms such as disorientation, drowsiness, signs of brainstem dysfunction, convulsions, coma and other signs. Encephalitis and seizures occur in complicated cases leading to coma within 2 to 4 days $[17,18]$. Segmental myoclonus was common in patients with encephalitis in Malaysia, and cases of meningitis, as well as encephalitis, were documented in the Philippines [17]. NiV infections in few patients emerge as respiratory diseases, like atypical pneumonia or acute respiratory distress syndrome. These patients may or may not show neurological signs. Renal impairment, Septicemia, bleeding from the gastrointestinal tract and other complications are observed in severely ill patients [19]. Survivors of encephalitis may have mild to severe residual neurological deficits, or in a vegetative state. Some people infected with Nipah virus develop recurred encephalitis or late-onset encephalitis, months or years afterward. The clinical signs usually develop acutely, with symptoms that may include headache, fever, seizures and focal neurological signs. Some cases are life-threatening. The incubation period of NiV infection is about 4 to 14 days and also seen some patients up to 45 days [20].

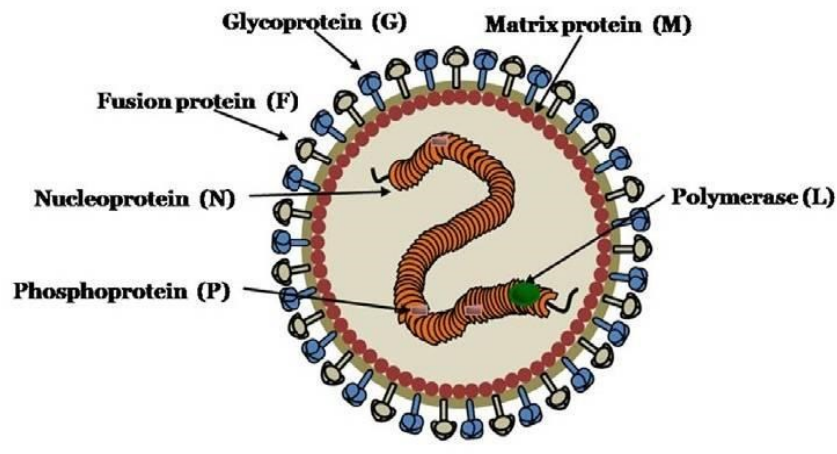

Figure 1: Structure of Henipavirus [15]

\section{Diagnosis:}

Oro-pharyngeal/nasal swabs, urine, and serum can be used for isolation from live animals, while the brain, lung, kidney, and spleen samples can be used postmortem [21]. If possible, urine should also be collected for analysis. As per biosecurity protocols, stringent use of personal protective equipment should be used when sampling with suspected NiV infection.

\section{Detection of Nucleic Acids, Virus, or Antigens:}

Virus separation should be done for exact diagnosis in the affected area with a newly suspected epidemic. The oropharyngeal and nasal swabs in 2 days post-infection are collected for NiV detection. Diagnosed NiV infected person goes on shedding virus up to 21 days postinfection [4]. A cytopathic effect is generally observed within 2 to 3 days, but multiple passages of 5 days each are recommended before confirming that a sample is $\mathrm{NiV}$ negative. Quantitative real-time polymerase chain reaction primers and probes are developed for the identification of the nucleocapsid gene of $\mathrm{NiV}[14,22]$.

Immunohistochemistry can be used to detect NiV. The nucleocapsid protein antigen is generally targeted. With the help of immunohistochemistry detection of phosphoprotein, an antigen is also possible, although nucleocapsid protein antigen is expressed in larger values than phosphoprotein antigen and hence it has significant diagnostic value.

Immunofluorescence can speedily detect $\mathrm{NiV}$ but cannot distinguish between $\mathrm{HeV}$, since mono-specific antisera to characteristic proteins of $\mathrm{NiV}$ will cross-react with $\mathrm{HeV}$. Negative contrast electron microscopy may be employed to identify viral particles.

\section{Detection of Antibody:}

An indirect enzyme-linked immunosorbent assay (ELISA) using recombinant $\mathrm{NiV} \mathrm{N}$ protein as an antigen has been employed as a diagnostic test. Recombinant proteins permit use of the ELISA to test samples that have been treated to inactivate the virus in biosafety level (BSL) 2 diagnostic labs [7].

Virus neutralization tests (VNT) have been employed for high-throughput screening in BSL2 diagnostic laboratories using recombinant vesicular stomatitis virus (rVSV) expressing $\mathrm{NiV}$ fusion protein and glycoprotein [13].

To detect both, antibody inhibition of ephrin-B2 receptor binding and antibody binding to recombinant soluble $\mathrm{HeV}$ or NiV G protein multiplexed microsphere immunoassays have been employed. Spectrally distinct microspheres determine specific and sensitive quantification and distinguish between $\mathrm{HeV}$ and $\mathrm{NiV}$ antibodies in a sample [23].

\section{Prevention, control and Treatment}

The treatment is limited to supportive care as there are no medications or vaccines available against $\mathrm{NiV}$-infection to date [24, 25]. After confirmation of diagnosis immediately admit the patient in the ICU under close monitoring for 24 hours. Treatment on fever and the other neurological symptoms should be taken care on priority basis in ICU. The symptoms of nausea, vomiting and convulsions may be alleviated by Ribavirin [7]. The patient should be well hydrated. Preventive measures are only option as there are no other alternatives for treatment of disease. The following preventive measures are recommended [26, 27].

1. All fruits that are bitten by infected animals should be avoided and also these fruits should not be given to farm animals.

2. Infected people or animals should be kept isolated and their movement should be restricted. The instrument used by patients should be autoclaved with the use of glutaraldehyde solution (2\%). Disposable materials should be used for the patient.

3. The alcohol-based solution is recommended for hand washing for about 20 seconds. Wearing of N95 mask is advised during investigational sampling from patient. 
4. Clean all the utensils used by an infected person with an alkaline solution $(\mathrm{pH} \mathrm{8.5)}$ and also wash the fruits and vegetables with water after adding some amount of baking soda or sodium hydrogen carbonate for one minute.

5. Alkaline detergents should be used for cleaning and disinfection of farm animals.

6. Suspicion of epidemics, the animals should be quarantined immediately. Killing and burial or incineration of infected animals can be essential to reduce the risk of transmission under expert supervision.

7. Avoid contact of body fluids of patients to the employees, health care team members and others [28].

8. If the domestic animals show weakness and runny nose, a veterinarian should be consulted urgently.

9. NiV infected people should not get in close physical contact with anyone.

\section{Conclusion}

Nipah virus infection is a newly developed zoonotic disease. Hence public should know about this illness. The creation of awareness regarding $\mathrm{NiV}$ will be helpful for preventing the transmission and occurrence of this disease. The clinical signs are headache, fever dizziness and vomiting, followed by disorientation, drowsiness and mental confusion. There is no particular vaccine and medication currently available for either humans or animals. The treatment is currently limited to supportive care. The knowledge about the preventive measures of transmission of disease is the only option available to mankind.

Conflicts of Interest: The authors declare no conflict of interest

\section{References}

[1] Rollin PE. Nipah Virus Disease. Emerg Infect Dis [Internet. 2014 Jan 1 [cited 2019 Oct;175-84. Available from. Available from: https:// www.sciencedirect.com/science/article/pii/ B9780124169753000133?via\%3Dihub [Google Scholar]

[2] Vandali V, Biradar RB. Nipah Virus ( Niv ) Infection: A Systematic Review. JOJ Nurse Health Care 2018;8(1):1-5. doi: 10.19080/ JOJNHC.2018.08.555729. [Google Scholar]

[3] Upendrababu V. Nipah Virus Infection, a High Priority Disease: History, Facts, Transmission, Symptoms, Prevention and Treatment. Int J Biomed Sci Eng 2018;6(2):38. Available from: http:// www.sciencepublishinggroup.com/journal/ paperinfo?journalid $=259 \& \mathrm{doi}=10.11648 /$ j.ijbse.20180602.13 doi: j.ijbse.20180602.13. [Google Scholar]

$10.11648 /$

[4] Chua KB, Lam SK, Goh KJ, et al. The presence of nipah virus in respiratory secretions and urine of patients during an outbreak of nipah virus encephalitis in Malaysia. J Infect 2001;42(1):40-43. Available from: https://linkinghub.elsevier.com/ retrieve/pii/S0163445300907825 doi: 10.1053/ jinf.2000.0782. [Google Scholar]

[5] Kulkarni DD, Tosh C, Venkatesh G, Senthil Kumar D . Nipah virus infection: Current scenario. Indian J Virol 2013;24(3):398-408. Available from: http:// link.springer.com/10.1007/s13337-013-0171-y doi: 10.1007/s13337-013-0171-y. [Google Scholar]

[6] Alothman M, Bhat R, Karim AA. Antioxidant capacity and phenolic content of selected tropical fruits from Malaysia, extracted with different solvents. Food Chemistry 2009;115(3):785-788. Available from: https://linkinghub.elsevier.com/ retrieve/pii/S030881460801457X doi: 10.1016/ j.foodchem.2008.12.005. [Google Scholar]

[7] Angeletti S, Lo Presti A, Cella E, Ciccozzi M. Molecular epidemiology and phylogeny of Nipah virus infection: A mini review. Asian Pacific Journal of Tropical Medicine 2016;9(7):630-634. Available from: http://linkinghub.elsevier.com/ retrieve/pii/S1995764516301006 doi: 10.1016/ j.apjtm.2016.05.012. [Google Scholar]

[8] Luby SP. The pandemic potential of Nipah virus. Antiviral Research 2013;100(1):38-43. Available from: https://linkinghub.elsevier.com/retrieve/pii/ S0166354213001988 doi: 10.1016/ j.antiviral.2013.07.011. [Google Scholar]

[9] Ross R. The pathogenesis of atherosclerosis: a perspective for the 1990s. Nature 1993;362 (6423):801-809. Available from: http:// www.nature.com/articles/362801a0 doi: 10.1038/362801a0. [Google Scholar]

[10] Hsu VP, Hossain MJ, Parashar UD, Ali MM, Ksiazek TG, Kuzmin I, et al. Nipah virus encephalitis reemergence, Bangladesh. Emerg Infect Dis. 2004 Dec;10(12 2082;PMCID(12):2082-2087. Available from: http://wwwnc.cdc.gov/eid/ article/10/12/04-0701 article.htm PubMed PMID: 15663842. doi: 10.3201/eid1012.040701. [Google Scholar]

[11] Gurley ES, Montgomery JM, Hossain MJ, et al. Person-to-person transmission of Nipah virus in a Bangladeshi community. Emerg Infect Dis 2007;13 (7):1031-1037. Available from: http:// wwwnc.cdc.gov/eid/article/13/7/06-

1128 article.htm doi: eid1307.061128. [Google Scholar]

[12] Aljofan M, Saubern S, Meyer AG, Marsh G, Meers J, Mungall BA. Characteristics of Nipah virus and Hendra virus replication in different cell lines and their suitability for antiviral screening. Virus Res. 2009 Jun;142(1-2):92-9. Epub 2009 Jan;PubMed Central PMCID(1-2):92-99. Available from: https:// linkinghub.elsevier.com/retrieve/pii/

S0168170209000227 PubMed PMID: 19428741. doi: 10.1016/j.virusres.2009.01.014. [Google Scholar]

[13] Yabukarski F, Lawrence P, Tarbouriech N, et al. Structure of Nipah virus unassembled nucleoprotein in complex with its viral chaperone. Nat Struct Mol Biol 2014;21(9):754-759. Available from: http:// www.nature.com/articles/nsmb.2868 doi: 10.1038/ nsmb.2868. [Google Scholar] 
[14] Vera-Velasco NM, García-Murria MJ, Sánchez del Pino, M. (Manuel), Mingarro I, Martinez-Gil L. Proteomic composition of Nipah virus-like particles. Journal of Proteomics 2018;172(August):190-200. Available from: https://linkinghub.elsevier.com/ retrieve/pii/S187439191730369X doi: 10.1016/ j.jprot.2017.10.012. [Google Scholar]

[15] Rockx B, Winegar R, Freiberg AN. Recent progress in henipavirus research: molecular biology, genetic diversity, animal models. Antiviral research 2012 Aug;95(2):135-49. Available from: https:// linkinghub.elsevier.com/retrieve/pii/ S0166354212001234 doi: 10.1016/ j.antiviral.2012.05.008. [Google Scholar]

[16] Satterfield BA, Cross RW, Fenton KA, et al. The immunomodulating $\mathrm{V}$ and $\mathrm{W}$ proteins of Nipah virus determine disease course. Nat Commun 2015;6 (May):1-15. Available from: http:// www.nature.com/articles/ncomms8483 doi: 10.1038/ncomms8483. [Google Scholar]

[17] Health ISP. Nipah Virus Barking Pig Syndrome, Porcine Respiratory and Encephalitis Syndrome, Porcine Respiratory and Neurologic Syndrome. 2011:1-9.http://www.cfsph.iastate.edu/Factsheets/ pdfs/nipah.pdf

[18] Bellini WJ, Harcourt BH, Bowden N, Rota PA. Nipah virus: An emergent paramyxovirus causing severe encephalitis in humans. J Neurovirol 2005;11 (5):481-487. Available from: http:// link.springer.com/10.1080/13550280500187435 doi: 10.1080/13550280500187435. [Google Scholar]

[19] Ahmad SB, Tan CT. Nipah encephalitis - an update. Med J Malaysia 2014;69(August):103-111. [Google Scholar]

[20] Wong KT, Shieh WJ, Kumar S, et al. Nipah virus infection: Pathology and pathogenesis of an emerging paramyxoviral zoonosis. Am J Pathol 2002;161(6):2153-2167. Available from: https:// linkinghub.elsevier.com/retrieve/pii/ S0002944010644938 doi: 10.1016/S0002-9440(10) 64493-8. [Google Scholar]

[21] Sharma V, Kaushik S, Kumar R, Yadav JP, Kaushik S. Emerging trends of Nipah virus: A review. Rev Med Virol 2019;29(1):1-6. doi: 10.1002/ rmv.2010. [Google Scholar]
[22] Bettio LE, Freitas AE, Neis VB, Santos DB, Ribeiro $\mathrm{CM}$, Rosa PB, et al. Guanosine prevents behavioral alterations in the forced swimming test and hippocampal oxidative damage induced by acute restraint stress. Pharmacol Biochem Behav 2014; 127:7-14. Available from: https:// linkinghub.elsevier.com/retrieve/pii/ S0091305714002767 PubMed PMID: 25316306. doi: 10.1016/j.pbb.2014.10.002. [Google Scholar]

[23] Matthew I. Bonaparte, Antony S. Dimitrov, Katharine N. Bossart, Gary Crameri, Bruce A. Mungall, Kimberly A. Bishop, Vidita Choudhry, Dimiter S. Dimitrov, Lin-Fa Wang, Bryan T. Eaton, and Christopher C. Broder. Ephrin-B2 ligand is a functional receptor for Hendra virus and Nipah virus. PNAS 2005;102(30):10652-10657. [Google Scholar]

[24] Narang R. Nipah virus: Biology, disease, treatment, control, and prevention. J Mahatma Gandhi Inst Med Sci 2018;23(2):65-8. Available from: https:// doi.org/10.4103/jmgims.jmgims 3918 doi: 10.4103/jmgims.jmgims_39_18._[Google Scholar]

[25] Satterfield BA, Dawes BE, Milligan GN. Status of vaccine research and development of vaccines for nipah virus. Vaccine 2016;34(26):2971-5. Available from: https://linkinghub.elsevier.com/retrieve/pii/ S0264410X16002966 doi: 10.1016/ j.vaccine.2015.12.075. [Google Scholar]

[26] WHO guideline for Management Prevention and Control of Nipah Virus Infection, Institute of epidemiology disease control and research, Bangladesh, 2016, 31-32

[27] Wong KT, Shieh WJ, Kumar S, Norain K, Abdullah W, Guarner J, Goldsmith CS, Chua KB, Lam SK, Tan CT, Goh KJ, Chong HT, Jusoh R, Rollin PE, Ksiazek TG, Zaki SR, , Group NVPW. Nipah virus infection: pathology and pathogenesis of an emerging paramyxoviral zoonosis. Am J Pathol. 2002 Dec;161(6 2153;PMCID. PubMed PMID: 12466131. doi: 10.1016/S0002-9440(10)644938. [Google Scholar]

[28] Chadha MS, Comer JA, Lowe L, et al. Nipah virusassociated encephalitis outbreak, Siliguri, India. Emerg Infect Dis 2006;12(2):235-240. Available from: http://wwwnc.cdc.gov/eid/article/12/2/051247 article.htm doi: eid1202.051247. [Google Scholar] 